\begin{tabular}{|c|c|c|c|}
\hline $\begin{array}{l}\text { RESEARCH } \\
\text { ARTICLE }\end{array}$ & $\begin{array}{r}\text { ADVANCE RESEAR } \\
\text { volume } 8 \mid \text { Issu }\end{array}$ & $\begin{array}{l}\text { OCIAL SCIENCE } \\
31-6418\end{array}$ & \\
\hline $0=$ & DOI: 10.15740/HAS/ARJSS/8.1/80-84 & Visit us : www.researchjournal.co.in & \\
\hline
\end{tabular}

\title{
Problems and issue faced by working women in Amreli city
}

Jiju Vyas, Hemangi D. Mehta* and Neha Tiwari

Polytechnic in Home Science (JAU), AMRELI (GUJARAT) INDIA

(Email: hemangidmehta@gmail.com)

\section{ARTICLE INFO : \\ Received \\ Revised \\ : 27.04 .2017 \\ Accepted \\ 09.05 .2017 \\ KEY WORDS : \\ Household activities, Working women, Mental harassment, Work place}

HOW TO CITE THIS ARTICLE : Vyas, Jiju, Mehta, Hemangi D. and Tiwari, Neha (2017). Problems and issue faced by working women in Amreli city. Adv. Res. J. Soc. Sci., 8 (1) : 80-84, DOI: 10.15740/HAS/ARJSS/8.1/80-84.

\begin{abstract}
The financial demands on the Indian families are becoming rise day by day working women in India are faced with lot more challenges that their counterparts in the other part of the world. The sky rocketing cost of living increasing expenses on education of children increasing cost of housing properties in India force every family in India to look for ways and means of increasing the house hold income. As a result, women in India who were mostly known as homemakers are forced to go for jobs and take up evencareers that were considered and suitable for men such as working in might shifts in call centers. Indian Society is extremely hierarchical with virtually every one ranked relative to after according to their caste class wealth and power. This ranking even exists in areas where it is not openly acknowledged, such as certain business settings. Though specific customs vary from religion to religion within the country there are different standards of behavior for men and women that carry over info the work environment. This paper examines the problems and issue faced by working women in Amrelicity. The research objective was to know the knowledge about the problem and challenge faced by urban working women in the workplace, farther the study also aims also at finding out the organizational support for women employers the present study surveyed only urban women employer. The study was conducted within Amrelicity. Data was collected from working women of the organized sector using mix methods approach that included face to face interview and by questionnaire. 60 samples were selected for present study from different areas of city. The result conducted that different women have different perception of their heads fears, frustration etc.
\end{abstract}

